\title{
Nonasthmatic chronic cough: No effect of treatment with an inhaled corticosteroid in patients without sputum eosinophilia
}

\author{
Marcia MM Pizzichini MD ${ }^{1}$, Emilio Pizzichini $\mathrm{MD}^{1}$, Krishnan Parameswaran $\mathrm{MD}^{2}$, Lynda Clelland \\ $\mathrm{RN}^{2}$, Ann Efthimiadis $\mathrm{MLT}^{2}$, Jerry Dolovich $\mathrm{MD}^{2}$, Frederick E Hargreave $\mathrm{MD}^{2}$ \\ ${ }^{1}$ Respiratory Division (NUPAIVA), Department of Internal Medicine, University of \\ Santa Catarina (UFSC), Florianópolis, Brazil; ${ }^{2}$ Asthma Research Group, Departments of \\ Medicine and Paediatrics, St Joseph's Hospital and McMaster University, Hamilton, Ontario
}

MMM Pizzichini, E Pizzichini, K Parameswaran, et al. Nonasthmatic chronic cough: No effect of treatment with an inhaled corticosteroid in patients without sputum eosinophilia. Can Respir J 1999;6(4):323-330.

BACKGROUND: Inhaled corticosteroids are effective in suppressing a chronic cough without asthma associated with sputum eosinophilia.

OBJECTIVE: To investigate the inflammatory characteristics in the induced sputum of patients with a chronic cough without asthma or known cause and the effects of budesonide treatment on chronic cough in those patients.

PATIENTS AND METHODS: Forty-four adults (mean [minimum, maximum] age of 45 years [20,75], 28 women, 17 atopic subjects and 32 nonsmokers]), with a daily bothersome cough for at least one year and who had no evidence of asthma or other known cause for the cough, were consecutively enrolled. The trial was a randomized, double-blind, controlled parallel group trial of budesonide $400 \mathrm{mg}$ twice daily for two weeks versus placebo. Patients then received open administration of the same dose of budesonide for a further two weeks. Sputum was induced before and at the end of each treatment period. Cough severity was documented by a visual analogue scale.

RESULTS: Thirty-nine (89\%) patients produced mucoid sputum after induction on at least one study visit. At baseline, the majority (59\%) had a mild elevation in the median proportion of neutrophils (65\%). All had elevated fluid phase levels of fibrinogen $(3200 \mu \mathrm{g} / \mathrm{L})$ and albumin $(880 \mu \mathrm{g} / \mathrm{L})$, and high levels of interleukin- 8 and substance P. Interleukin- 8 correlated with neutrophils ( $\mathrm{rho}=0.72, \mathrm{P}<0.001$ ), fibrinogen $(\mathrm{rho}=0.65$, $\mathrm{P}<0.001)$, albumin $(\mathrm{rho}=0.67, \mathrm{P}=0.001)$ and eosinophil cationic protein (rho $=0.60, \mathrm{P}=0.001$ ). Substance $\mathrm{P}$ correlated with albu$\min (\mathrm{rho}=0.60, \mathrm{P}=0.006)$. No subject had an increase in eosinophils. Treatment with budesonide did not affect cough or sputum measurements.

CONCLUSIONS: Patients with nonasthmatic chronic cough enrolled in this study had evidence of a mild neutrophilia and/or microvascular leakage. Chronic cough did not respond to treatment with budesonide, perhaps because the cause was not associated with sputum eosinophilia.

Key Words: Airway inflammation; Budesonide; Cough; Induced sputum; Sputum cell counts; Sputum fluid phase measurements 


\section{Toux chronique d'origine non asthmatique : la corticothérapie en aérosol inefficace chez les pa- tients sans éosinophilie dans les expectorations}

CONTEXTE : Les corticostéroïdes en aérosol suppriment la toux chronique d'origine non asthmatique, associée à l'éosinophilie dans les expectorations.

OBJECTIF : Étudier les caractéristiques de l'inflammation dans les expectorations de patients présentant une toux chronique d'origine non asthmatique ou d'origine inconnue, ainsi que les effets d'un traitement au budénoside sur la toux chronique de ces mêmes patients.

PATIENTS ET MÉTHODE : Quarante-quatre (44) adultes (âge moyen : 45 ans [minimum-maximum : 20-75]; 28 femmes; 17 cas atopiques; 32 non-fumeurs) présentant tous les jours depuis au moins un an une toux gênante d'origine non asthmatique ou d'origine inconnue ont participé consécutivement à l'étude. Il s'agissait d'un essai à double insu, avec répartition aléatoire, contrôlé contre placebo, dans lequel le groupe expérimental prenait $400 \mathrm{mg}$ de budénoside, deux fois par jour pendant deux semaines. Les patients ont par la suite reçu, en mode ouvert, la même dose de budénoside pour une autre période de deux semaines. On a procédé à un examen des expectorations, après provocation de la toux, au début et à la fin de chaque période de traitement. L'intensité de la toux a été évaluée à l'aide d'une échelle analogique visuelle.

RÉSULTATS : Quatre-vingt-neuf pour cent (89\%) des patients ont produit au moins une fois des expectorations mucoïdes après provocation de la toux. La majorité (59\%) présentait, au départ, une légère élévation dans la proportion médiane des neutrophiles (65\%). Tous avaient, en phase fluide, des concentrations élevées de fibrinogène $(3200 \mathrm{mg} / \mathrm{L})$ et d'albumine $(880 \mathrm{mg} / \mathrm{L})$ ainsi que d'interleukine 8 et de substance P. L'interleukine 8 a été mise en corrélation avec les neutrophiles ( $r h o=0,72 ; \mathrm{p}<0,001)$, le fibrinogène ( $r h o=0,65 ; \mathrm{p}<0,001)$, l'albumine $(\mathrm{rho}=0,67 ; \mathrm{p}=0,001)$ et la protéine cationique des éosinophiles ( $\mathrm{rho}=0,60 ; \mathrm{p}=0,001)$. La substance $\mathrm{P}$ a été mise en corrélation avec l'albumine ( $r h o=0,60 ; \mathrm{p}=0,006)$. Aucun sujet n'a présenté d'augmentation du nombre d'éosinophiles. Le traitement au budénoside n'a pas modifié les mesures de la toux et des expectorations.

CONCLUSION : Les patients souffrant de toux chronique d'origine non asthmatique, admis dans l'étude, présentaient des signes de polynucléose neutrophile légère et de fuite microvasculaire. La toux chronique n'a pas réagi au traitement au budésonide, peut-être parce que la cause n'était pas associée à l'éosinophilie dans les expectorations.
$\mathrm{C}$ hronic cough is common and often bothersome. Clinical management attempts to recognize the cause and treat the cough. Frequent causes of cough include asthma, smokers' or infective bronchitis, postnasal drip, gastroesophageal reflux and drugs (1-4). Often, however, no cause can be identified, and the patient is given trials of treatment.

A new investigative tool in chronic cough and airway disease is the examination of induced sputum for cells and fluid phase markers of inflammation (5). Sputum examination was responsible for identifying the occurrence of chronic cough with sputum eosinophilia in patients who did not have the variable airflow limitation of asthma (6). The cough and eosinophilia were reversed by treatment with an inhaled steroid (7). Other studies of asthma (8) and chronic airflow limitation $(9,10)$ suggest that sputum eosinophilia is an important predictor of benefit from steroid treatment. However, sputum eosinophilia appears to be present in only about $10 \%$ of patients with nonasthmatic chronic cough (2).

The presence of other inflammatory cells and mediators in the airways of subjects with nonasthmatic chronic cough may be important in its pathogenesis. In a recent study of 19 subjects with chronic cough of varying etiology, induced sputum showed a predominance of neutrophils and increased levels of tumour necrosis factor-alpha and interleukin (IL)-8 (11). Other proinflammatory mediators that are localized to sensory nerves in the airways, such as substance P, may also be involved in the pathogenesis but have not been investigated.

In the present study, we selected patients with a chronic cough who did not have asthma or an other known cause for the cough. We examined the characteristics of the airway inflammation by using induced sputum and the effects of treatment with inhaled budesonide in a randomized controlled trial. The study was designed to compare the treatment effect in patients with the eosinophilic versus noneosinophilic sputum but, by chance, no patient presented with eosinophilia.
We also documented the local side effects of budesonide because its use in the treatment of chronic cough is not an approved use of the drug.

\section{PATIENTS AND METHODS}

Patients: Adults with a daily bothersome cough for at least one year were recruited from the Firestone Regional Chest and Allergy Clinic, Hamilton, Ontario and by advertisement (Table 1). They were atopic or nonatopic, and non- or exsmokers for more than six months. Patients were considered eligible if they had no other respiratory symptoms, no indication of a respiratory infection in the previous month or history of chronic bronchitis, no radiological evidence of chest disease, no other recognized condition or drugs to account for the cough, no cardiovascular or renal disease requiring regular medication, and were not pregnant or had not received corticosteroids within the month. Symptomatic gastroesophageal reflux (heartburn or acid regurgitation on at least three days/week) was investigated and treated, and, if the cough was not improved, patients were enrolled in the study (two placebo, three budesonide). Patients with postnasal drip, who had been previously investigated and treated, and who had no sinusitis on sinus X-rays were also enrolled (three placebo, six budesonide). The patients had no evidence of asthma as indicated by a forced expiratory volume in $1 \mathrm{~s}\left(\mathrm{FEV}_{1}\right)$ greater than $70 \%$ predicted, an $\mathrm{FEV}_{1} /$ vital capacity (VC) of greater than $70 \%$, little response to a bronchodilator and normal methacholine airway responsiveness (a provocation concentration of methacholine to cause a fall in $\mathrm{FEV}_{1}$ of $20 \%$ [ $\mathrm{PC}_{20}$ ] of more than $8 \mathrm{mg} / \mathrm{mL}$ ). The study was approved by the hospital research committee, and all patients gave written informed consent.

Study design: This was a single-centre, randomized, double-blind, placebo controlled, parallel group trial with three visits at the same time of the day at intervals of two weeks. At a screening visit a detailed structured history, 
physical examination, record of previous or current medications and previous investigation, spirometry, methacholine inhalation test, allergy skin prick tests, and chest x-ray (if not performed in the previous three months) were performed. At the first visit, patients who met the inclusion criteria were consecutively enrolled and randomized to receive budesonide Turbuhaler (Astra Pharma Canada Inc, Mississauga, Ontario) $400 \mu \mathrm{g} /$ inhalation twice daily or identical placebo Turbuhaler (one inhalation twice daily) for two weeks. The randomization sequence was generated by computer off-site, was concealed from the investigators and administered by a research nurse. Patients completed a questionnaire of cough frequency and characteristics, graded cough discomfort on a visual analogue scale (VAS), and underwent sputum induction and blood collection. They were instructed how to use the Turbuhaler, and how to avoid local side effects by rinsing the mouth with water and gargling after inhalation of the study medication. At the second visit, the study medication was discontinued and replaced by open treatment with budesonide Turbuhaler $400 \mu \mathrm{g}$ twice daily for a further two weeks. At visits 2 and 3, cough discomfort VAS, spirometry, blood and sputum measurements were repeated. Local side effects were recorded.

The primary outcome was improvement in cough discomfort as measured by the VAS, and this was, before analysis, considered clinically important only if cough discomfort was reduced by $50 \%$ or greater. Secondary outcomes were sputum total and differential cell counts, fluid phase eosinophil cationic protein (ECP), IL-8, fibrinogen, albumin and substance $\mathrm{P}$, and local side effects from treatment.

Clinical methods: Subject and cough characteristics were documented by structured questionnaires. Cough discomfort was rated using a 9-point Likert scale where 1 was virtually unbearable, the most severe discomfort or distress ever, and 9 was absent, none at all. Cough discomfort in the previous two days was also graded by the subject on a $100 \mathrm{~mm}$ horizontal VAS, where zero was no cough and 100 was at its worst. Local side effects of inhaled budesonide were also assessed by a structured questionnaire and by oropharyngeal inspection. Spirometry, methacholine inhalation tests and allergy skin prick tests were performed by standard methods (12-15). Sputum was induced by the inhalation of an aerosol of hypertonic saline as described by Pin et al (16).

Sputum examination: Sputum was selected from the expectorate and processed as described elsewhere (5). The success of the selection was confirmed by a proportion of squamous epithelial cells of $5 \%$ or less. The concentration of ECP $(\mu \mathrm{g} / \mathrm{L})$ in the thawed supernatant was determinated using a sensitive radioimmunoassay (RIA, Kabi Pharmacia Diagnostics AB, Uppsala, Sweden). Fibrinogen was measured by a 'sandwich' ELISA assay using a rabbit antihuman fibrinogen antibody (Dako A080, Dako Diagnostics Canada Inc, Mississauga, Ontario). Sputum albumin was determined by the standard method. Substance $P$ was determined by a radioimmunoassay using an antisubstance P antibody $3.0 \mu \mathrm{L} \mathrm{im-}$ munoglobulin (Ig)G \#1 and $2.5 \mu \mathrm{L} \mathrm{IgG} \mathrm{\# 2} \mathrm{or} \mathrm{less} \mathrm{(Peninsula}$ Laboratories, Belmont, California). IL-8 was measured by
TABLE 1

Subject characteristics in a study of patients with nonasthmatic chronic cough

\begin{tabular}{|c|c|c|}
\hline Characteristic & Placebo $(n=23)$ & Budesonide $(n=21)$ \\
\hline Age (years) ${ }^{*}$ & $47(22-72)$ & $43(20-75)$ \\
\hline Sex, male & 10 & 6 \\
\hline Smoking (non [ex]) & $17(6)$ & $15(6)$ \\
\hline Atopic (n) & 9 & 8 \\
\hline $\mathrm{FEV}_{1}(\mathrm{~L})$ & $3.5(3.0,3.6)$ & $3.6(3.9,4.0)$ \\
\hline $\mathrm{FEV}_{1}(\%$ predicted $)$ & $102(99,103)$ & $101(95,106)$ \\
\hline $\mathrm{FEV}_{1} / \mathrm{VC}(\%)$ & $80(77,83)$ & $82(78,85)$ \\
\hline $\begin{array}{l}\Delta \mathrm{FEV}_{1} \text { after } \\
\text { bronchodilator } \\
\text { (\% from predicted) }\end{array}$ & $2.5(1.2,3.8)$ & $3.5(1.2,5.1)$ \\
\hline $\begin{array}{l}\mathrm{PC}_{20} \text { methacholine } \\
(\mathrm{mg} / \mathrm{mL})\end{array}$ & $>8.0$ & $>8.0$ \\
\hline $\begin{array}{l}\text { Previous cough } \\
\text { investigation (n) }\end{array}$ & 14 & 14 \\
\hline $\begin{array}{l}\text { Previous cough } \\
\text { treatment }(n)\end{array}$ & 14 & 12 \\
\hline $\begin{array}{l}\text { Previous inhaled } \\
\text { steroid trial }(n)\end{array}$ & 4 & 3 \\
\hline Cough duration (years) & $11.8(4.6,19.2)$ & $9.8(5.3,14.2)$ \\
\hline $\begin{array}{l}\text { Cough questionnaire } \\
\text { score }^{\dagger}\end{array}$ & $5.2(4.6,5.9)$ & $4.6(3.7,5.5)$ \\
\hline Cough VAS $(\mathrm{mm})^{\ddagger}$ & $51.0(41,61)$ & $61.4(51,72)$ \\
\hline
\end{tabular}

Data are expressed as mean $(95 \% \mathrm{Cl})$ or otherwise as specified. Atopic means one or more positive allergy skin prick tests. Forced expiratory volume in $1 \mathrm{~s}\left(F E V_{1}\right)$ predicted values from Crapo et al (12) or previous best in the past two years. ${ }^{*}$ Mean (minimum-maximum); ${ }^{\dagger} A$ 9-point Likert scale (see text); ${ }^{\ddagger} A 100 \mathrm{~mm}$ horizontal visual analogue scale (see text). $P C_{20}$ Provocation concentration of methacholine to cause a fall in FEV $V_{1}$ of $20 \%$; VAS Visual analogue scale; VC Vital capacity

quantitative 'sandwich' enzyme immunoassay (Quantikine, R\&D Systems Inc, Minneapolis, Minnesota). The limits of detection for ECP, fibrinogen, IL-8 and substance P were 2.0 $\mathrm{mg} / \mathrm{mL}, 0.79 \mathrm{mg} / \mathrm{L}, 25.6 \mathrm{pg} / \mathrm{mL}$ and $0.62 \mathrm{pg} / \mathrm{mL}$, respectively. Data analysis: Clinical variables were summarized by means and 95\% CI, except for $\mathrm{PC}_{20}$ data, which were log transformed and summarized by geometric mean. Sputum results were summarized by medians and interquartile range. Dependent variables with a non-normal distribution were log transformed before analysis. Between group differences of demographic characteristics and sputum measurements, with and without sputum neutrophilia, were examined by unpaired $t$ test. The effects of treatments on the dependent variables were compared via differences in means obtained from a linear model using the general linear model procedure of SPSS (Advanced Statistics 7.5 for Windows, SPSS Inc, Chicago, Illinois) including two baseline covariates (smoking and duration of cough in years). ANOVA was used in a model to examine the effect of treatment within groups on dependent variables. Correlations between variables were estimated by Spearman rank correlation coefficients (rho). To avoid correlations occurring by chance, only those rho $\geq 0.50$, with $\mathrm{P} \leq 0.01$ were considered relevant. All statistical tests were two sided, and significance was accepted at the $95 \%$ level. 


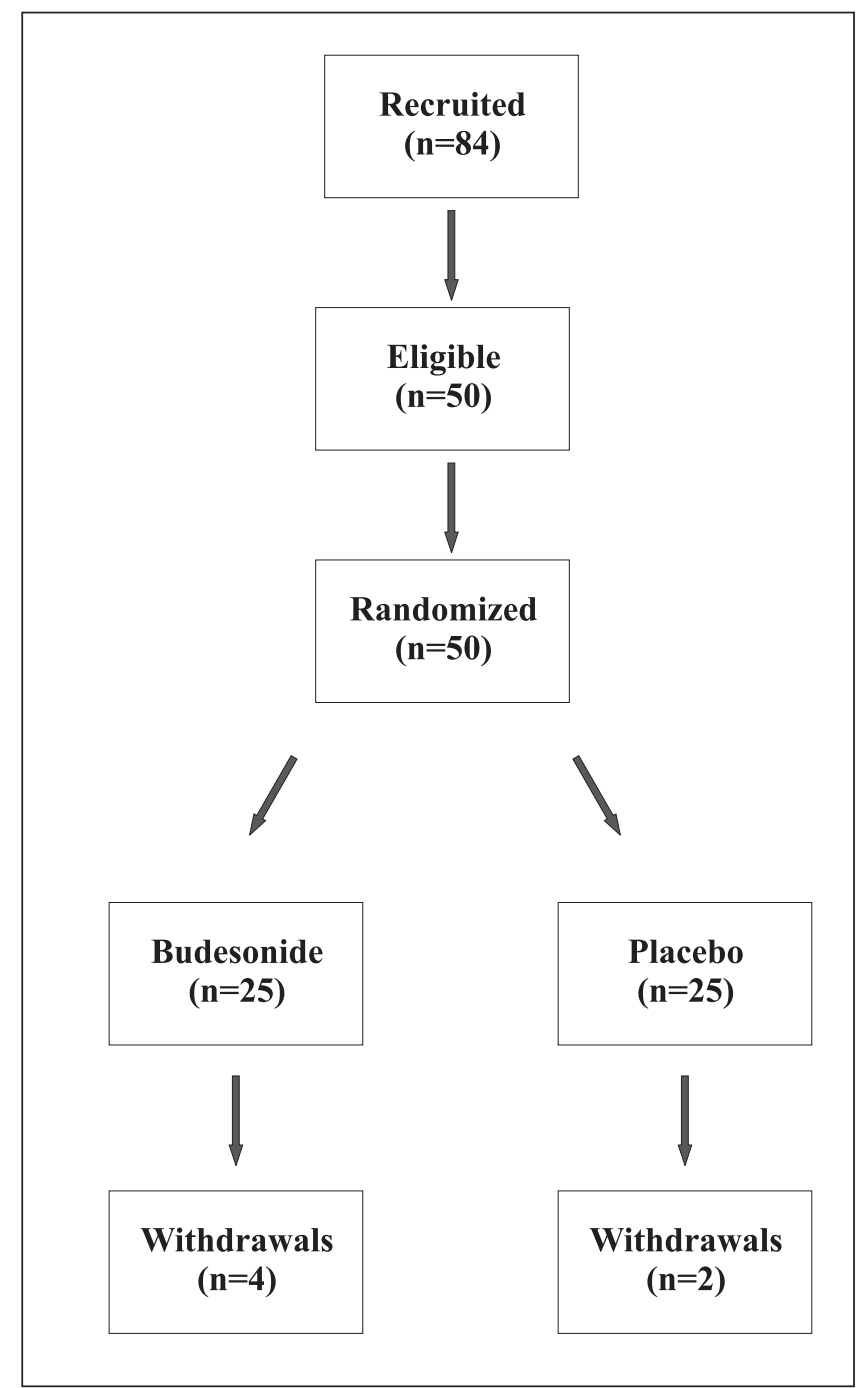

Figure 1) Flow diagram of randomized participants and withdrawals in a study of patients with nonasthmatic chronic cough

\section{RESULTS}

Randomization and withdrawals: Fifty patients were randomized to one or other study treatment (Figure 1). Twentyfive patients received budesonide and 25 placebo. Two patients (one placebo, one budesonide) were found ineligible after randomization, one because of an abnormal chest radiograph and the other because of documented gastroesophageal reflux; they were withdrawn from the study before the end of the first week. Four other patients (three on budesonide) were withdrawn before the end of the second week of treatment, three due to an intercurrent viral infection (one placebo, two budesonide) and one who did not return. These six patients were excluded from the analysis.

Characteristics of inflammatory indices in sputum before treatment: Of the 44 patients who completed the study, 39 (89\%) produced mucoid sputum after induction on at least one study visit. Thirty-two patients $(73 \%)$ produced sputum before any inhaled steroid treatment. Twenty-three patients $(52 \%)$ were able to produce sputum at each visit; their characteristics were the same as the remainder. The procedure of induction was safe as demonstrated by a trivial mean
$(95 \% \mathrm{CI})$ fall in the postbronchodilator $\mathrm{FEV}_{1}$ of $3.4 \%$ (2.8 to 4.0).

Sputum appearance, cell viability, total and differential cell counts, and the fluid phase measurements of the 32 patients who produced sputum before treatment (Table 2) were examined. In 19 (59\%) patients, the proportion and absolute number of neutrophils were above the upper limit for healthy patients. None of the patients had an increase in the proportion or absolute number of eosinophils $\left(0[0.01] \times 10^{6} / \mathrm{mL}\right)$. Sputum ECP levels were above the normal range only in seven patients. Fibrinogen levels were increased in each sputum sample, and this was accompanied by high levels of IL-8, albumin and substance P (the last two markers were measured only in 19 samples). These sputum findings were not explained by a previous history of smoking or an association of postnasal drip (six patients). Fluid phase markers did not differ significantly between patients with and without sputum neutrophilia.

The correlations between the inflammatory markers in sputum (Figure 2) were also studied. Fluid phase ECP was strongly correlated with neutrophils ( $\mathrm{rho}=0.61, \mathrm{P}=0.001$ ) but not with eosinophils ( $\mathrm{rho}=0.38, \mathrm{P}=0.06)$. IL- 8 was correlated with neutrophils ( $\mathrm{rho}=0.72, \mathrm{P}<0.001)$, fibrinogen $(\mathrm{rho}=0.65$, $\mathrm{P}<0.001$ ), albumin ( $\mathrm{rho}=0.67, \mathrm{P}=0.001)$ and $\mathrm{ECP}$ (rho=0.60, $\mathrm{P}=0.001)$. Substance $\mathrm{P}$ was correlated with albumin (rho=0.60, $\mathrm{P}=0.006$ ) but not with fibrinogen ( $\mathrm{rho}=0.48$, $\mathrm{P}=0.07)$.

Effect of treatment on cough: Cough discomfort before and after two weeks of treatment with placebo or budesonide was examined. The severity of cough discomfort before treatment did not differ between the treatment groups (Table 1) nor between patients with or without sputum neutrophilia (Table 2). The effects of two weeks treatment with budesonide on cough discomfort, as measured by the VAS, was similar to the placebo effect whether analyzed as the difference between actual values or as the difference between the percentage reduction in cough discomfort (Figure 3 ). The reduction in cough discomfort after two weeks treatment with open label budesonide was also similar in the two groups. A reduction of $50 \%$ or greater in cough discomfort (from baseline) after two weeks of blind budesonide or placebo occurred in only four patients of the budesonide group. In contrast, the two weeks of open treatment with budesonide produced a reduction of $50 \%$ or greater in cough discomfort (from baseline) in eight patients of the budesonide and in nine of the placebo group (Figure 3).

Effect of treatment on airway inflammation: The effect of treatment on airway inflammation was examined only in the 23 patients who produced sputum on each visit (Table 3 ). Treatment with budesonide for two or four weeks did not have a significant effect in any of the sputum inflammatory markers.

Local side effects: Four (three budesonide, one placebo) and 11 (five budesonide and six placebo) patients reported mild local side effects after two or four weeks of treatment, respectively. The side effects included hoarseness (six patients), sore throat (five patients), hoarseness and sore throat (two patients), and dry mouth (two patients). The only find- 

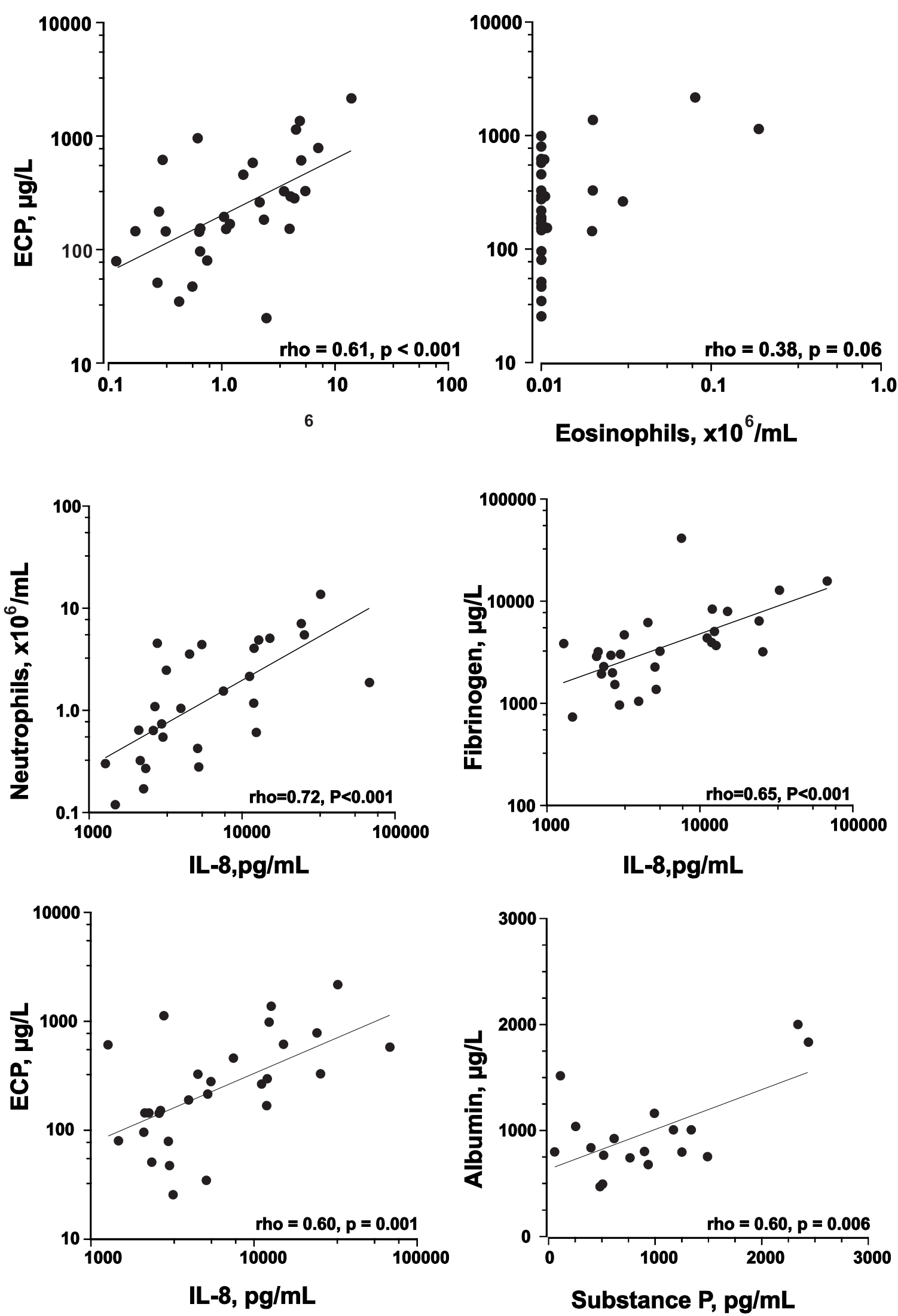

Figure 2) Correlations between sputum inflammatory indexes. A strong correlation was observed between eosinophil cationic protein (ECP) and neutrophils but not eosinophils. Sputum interleukin (IL)-8 was strongly correlated with neutrophils, fibrinogen and ECP. Substance P correlated only with albumin 
TABLE 2

Clinical features and sputum inflammatory indices in subjects with and without sputum neutrophilia

\begin{tabular}{|c|c|c|c|c|c|c|c|c|c|c|c|c|c|c|}
\hline \multirow[b]{2}{*}{ Subjects (n) } & \multicolumn{3}{|c|}{ Clinical features } & \multicolumn{11}{|c|}{ Sputum indices } \\
\hline & $\begin{array}{l}\text { VAS } \\
(\mathrm{mm})\end{array}$ & $\begin{array}{c}\text { Ex-S } \\
(n)\end{array}$ & $\begin{array}{l}\text { PND } \\
\text { (n) }\end{array}$ & $\begin{array}{c}\text { TCC } \\
\left(\times 10^{6} / \mathrm{mL}\right)\end{array}$ & $E(\%)$ & N (\%) & M (\%) & L (\%) & $\begin{array}{c}\text { BEC } \\
(\%)\end{array}$ & $\begin{array}{c}\text { ECP } \\
(\mu \mathrm{g} / \mathrm{L})\end{array}$ & $\begin{array}{c}F \\
(\mu g / m L)\end{array}$ & $\begin{array}{c}\text { Albumin } \\
(\mu \mathrm{g} / \mathrm{L})^{*}\end{array}$ & $\begin{array}{c}\text { IL-8 } \\
\text { (pg/L) }\end{array}$ & $\begin{array}{l}\text { Subst P } \\
(\mathrm{pg} / \mathrm{mL})^{\star}\end{array}$ \\
\hline $\begin{array}{l}\text { Neutrophilia } \\
\text { (19) }\end{array}$ & $52(44)$ & 6 & 3 & $3.8(3.9)$ & $0(0.3)$ & $65.0(42)$ & $35.0(40)$ & $\begin{array}{c}0.5 \\
(0.8)\end{array}$ & $\begin{array}{c}0 \\
(0.3)\end{array}$ & $\begin{array}{c}192 \\
(304)\end{array}$ & $\begin{array}{l}3200 \\
(3520)\end{array}$ & $\begin{array}{c}860 \\
(264)\end{array}$ & $\begin{array}{c}6480 \\
(11,790)\end{array}$ & $936(976)$ \\
\hline $\begin{array}{l}\text { No neutrophilia } \\
\text { (13) }\end{array}$ & $56(20)$ & 5 & 3 & $2.1(4.1)$ & $0(0.2)$ & $25.0(12)$ & $73(9.5)$ & $\begin{array}{c}0.5 \\
(1.1)\end{array}$ & $\begin{array}{c}0 \\
(0.8)\end{array}$ & $\begin{array}{c}180 \\
(549)\end{array}$ & $\begin{array}{l}2480 \\
(2800)\end{array}$ & $\begin{array}{l}920 \\
(564)\end{array}$ & $\begin{array}{c}3020 \\
(7400)\end{array}$ & $504(764)$ \\
\hline $\mathrm{P}$ & NS & NS & NS & 0.03 & NS & $<-0.001$ & $<0.001$ & NS & NS & NS & NS & NS & NS & NS \\
\hline $\begin{array}{l}\text { All subjects } \\
\text { (32) }\end{array}$ & $55(36)$ & 11 & 6 & $2.6(4.5)$ & $0(0.3)$ & $39(42)$ & $58(42)$ & $\begin{array}{l}0.5 \\
(0.9)\end{array}$ & $\begin{array}{c}0 \\
(0.3)\end{array}$ & $\begin{array}{c}192 \\
(440)\end{array}$ & $\begin{array}{l}3200 \\
(3040)\end{array}$ & $\begin{array}{c}880 \\
(284)\end{array}$ & $\begin{array}{c}4840 \\
(9650)\end{array}$ & $836(894)$ \\
\hline $\begin{array}{l}\text { Sputum values ( } \\
\text { subjects }^{\dagger}\end{array}$ & upper lim & for he & ealthy & 5.5 & 1.2 & 33.7 & 80.6 & 2.5 & 1.2 & 655 & 1275 & 588 & - & - \\
\hline
\end{tabular}

Data are expressed as median and interquartile range, $p$ values were calculated for differences between groups. *Measured only in 19 subjects; ${ }^{\dagger}$ From reference 5 BEC Bronchial epithelial cells; E Eosinophils; ECP Eosinophil cationic protein; Ex-S Ex-smokers; F Fibrinogen; IL Interleukin; L Lymphocytes; M Macrophages; N Neutrophils; NS Not significant; PND Postnasal drip; Subst P Substance P; TCC Total cell count; VAS Visual analogue scale

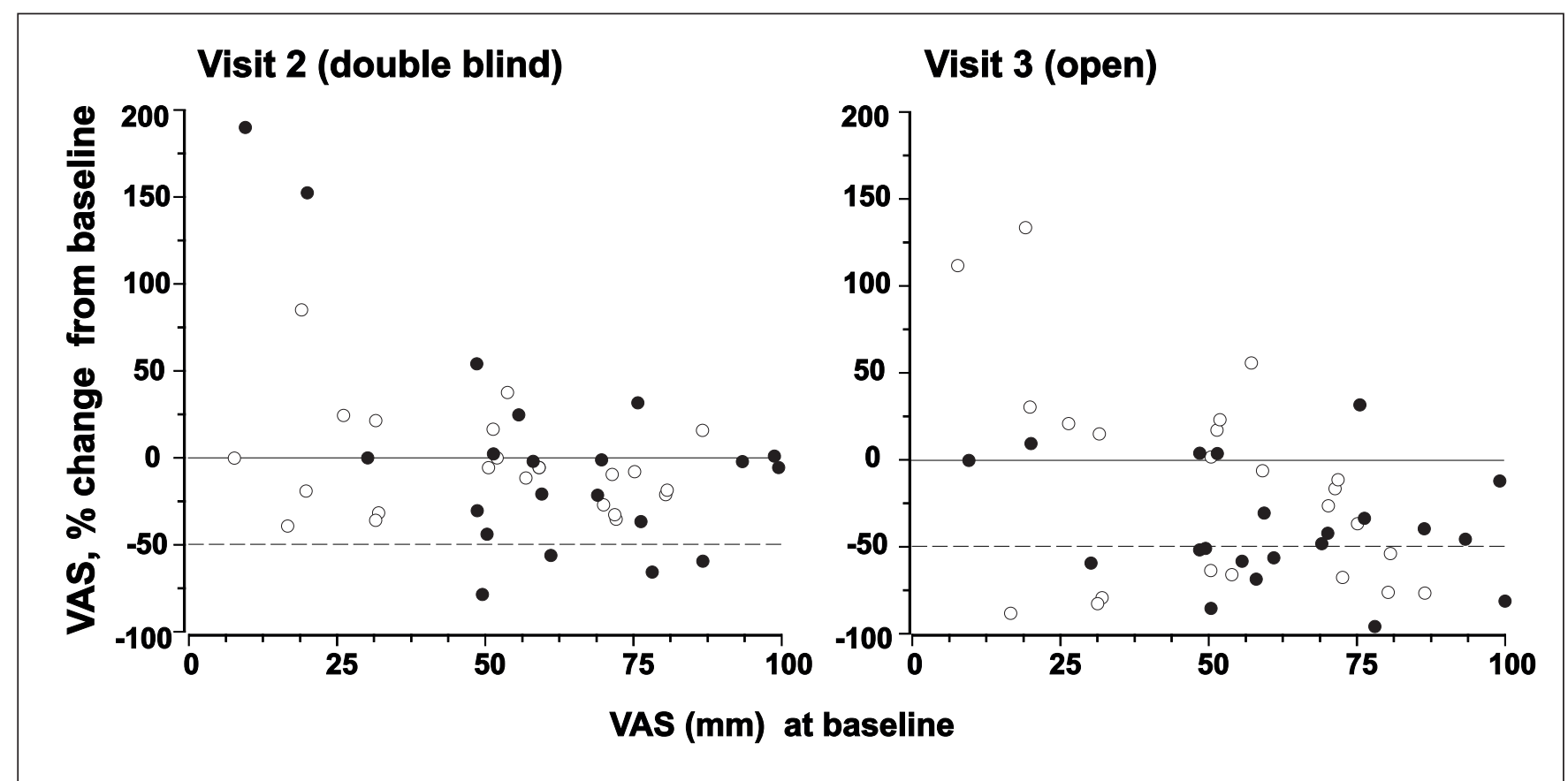

Figure 3) Effects of treatment on cough discomfort. The effect of budesonide treatment (closed circles) on cough discomfort was similar to placebo treatment (open circles). Continuous line represents no effect. Dashed line represents a $50 \%$ reduction from baseline in cough discomfort

ing observed on inspection was redness of oropharyngeal mucosa. No patient had to discontinue treatment because of the local effects.

\section{DISCUSSION}

This study demonstrates that chronic cough without asthma or known cause is associated with lower airway inflammation. The inflammatory response was noneosinophilic in all patients and neutrophilic in the majority, and this was accompanied by increased microvascular leakage (as measured by fibrinogen and albumin levels), high levels of IL-8 and substance P, and low levels of ECP. Treatment with inhaled budesonide $800 \mu \mathrm{g}$ daily for two or four weeks did not improve cough discomfort or sputum inflammatory indices, possibly because the cause was not associated with sputum eosinophilia.
There are still only a few investigations of airway inflammation in chronic cough in nonasthmatic patients or of its relevance to the effects of treatment. The studies differ in methods and subject selection. The emerging data are, not surprisingly, contradictory. Gibson et al (7) selected patients with eosinophilia, and observed that treatment with an inhaled steroid reversed the cough and eosinophilia. The eosinophilia was associated with IL-5 and granulocytemacrophage colony-stimulating factor mRNA expression in bronchoalveolar lavage cells (17). This condition, termed eosinophilic bronchitis without asthma (6), occurred in $10 \%$ of 30 consecutive adults with chronic cough referred to a tertiary care clinic (2). In contrast, Boulet et al (18) performed bronchial biopsies in patients with chronic cough associated with gastroesophageal reflux, postnasal drip or with no identifiable cause. They found an increase in mononuclear cells 
TABLE 3

Sputum inflammatory indexes before and after treatment with placebo or budesonide

\begin{tabular}{|c|c|c|c|c|c|c|c|c|c|c|c|}
\hline & $\begin{array}{l}\text { VAS* } \\
(\mathrm{mm})\end{array}$ & $\begin{array}{c}\text { TTC } \\
\left(\times 10^{6} / \mathrm{mL}\right)\end{array}$ & $E(\%)$ & N (\%) & M (\%) & L (\%) & $\begin{array}{c}\text { BEC } \\
(\%)\end{array}$ & $\begin{array}{c}E C P \\
(\mu \mathrm{g} / \mathrm{mL})\end{array}$ & $\begin{array}{c}\text { Fibrinogen } \\
(\mu \mathrm{g} / \mathrm{mL})\end{array}$ & $\begin{array}{c}\text { IL-8 } \\
\text { (pg/mL) }\end{array}$ & $\begin{array}{l}\text { Subs P } \\
(p g / m L)\end{array}$ \\
\hline \multicolumn{12}{|c|}{ Placebo group $(n=12)$} \\
\hline Baseline & $52(40)$ & $3.8(7.7)$ & $0(0.2)$ & $45(47)$ & $47(46)$ & $0.2(0.8)$ & $0(0.3)$ & $312(746)$ & $\begin{array}{c}3910 \\
(6360)\end{array}$ & $\begin{array}{c}6480 \\
(11,640)\end{array}$ & $936(824)$ \\
\hline Placebo & $48(30)$ & $3.5(2.1)$ & $0(0.3)$ & $53(22)$ & $42(24)$ & $0.3(1.2)$ & $0(0)$ & $320(624)$ & $\begin{array}{c}7120 \\
(3780)\end{array}$ & $\begin{array}{c}10,600 \\
(16,720)\end{array}$ & $636(534)$ \\
\hline $\begin{array}{l}\text { Open label } \\
\text { budesonide }\end{array}$ & $36(37)^{\star \star}$ & $4.2(3.3)$ & $0(0.3)$ & $38(33)$ & $59(33)$ & $0.3(0.3)$ & $0(0.3)$ & $320(858)$ & $\begin{array}{c}4560 \\
(7860)\end{array}$ & $\begin{array}{c}8200 \\
(11,300)\end{array}$ & $520(806)$ \\
\hline \multicolumn{12}{|c|}{ Budesonide group $(n=11)$} \\
\hline Baseline & $59(28)$ & $2.9(4.8)$ & $0(0.3)$ & $36(45)$ & $63(39)$ & $0.5(1.0)$ & $0(0.5)$ & $264(512)$ & $\begin{array}{c}3680 \\
(3600)\end{array}$ & $\begin{array}{c}4280 \\
(10,060)\end{array}$ & $904(884)$ \\
\hline Budesonide & $52(40)$ & $2.8(1.4)$ & $0(0.3)$ & $38(61)$ & $59(62)$ & $0.3(0.2)$ & $0(0)$ & $232(592)$ & $\begin{array}{c}4960 \\
(5720)\end{array}$ & $\begin{array}{c}8560 \\
(13,120)\end{array}$ & $434(540)$ \\
\hline $\begin{array}{l}\text { Open label } \\
\text { budesonide }\end{array}$ & $27(32)^{* *}$ & $2.2(3.4)$ & $0(0)$ & $35(41)$ & $65(40)$ & $0.2(0.8)$ & $0(0.5)$ & $128(272)$ & $\begin{array}{c}3440 \\
(6200)\end{array}$ & $\begin{array}{r}4840 \\
(4360)\end{array}$ & $564(382)$ \\
\hline
\end{tabular}

*Median values including all patients in each group; ${ }^{* *} P<0.05$ for within group comparison. BEC Bronchial epithelial cells; E Eosinophils; ECP Eosinophil cationic protein; IL Interleukin; N Neutrophils; M Macrophages; Subs P Substance P; TTC Total cell count; VAS Visual analogue scale

and epithelial cell damage without eosinophilia or neutrophilia. Also, MacGarvey et al (19), examining the bronchoalveolar lavage fluid of 28 patients with nonasthmatic nonproductive cough due to postnasal syndrome, gastroesophageal reflux or of unknown cause, reported a significant increase in both eosinophils and mast cells. These results, therefore, differ from those in the present study, presumably due to differences in subject selection or in the airway compartments studied.

Sputum neutrophilia in the present study was associated with elevated sputum IL-8 levels. This is not surprising because IL-8 is a neutrophil chemoattractant (20). The generally low levels of fluid phase ECP are in keeping with the absence of eosinophilia, although some patients had a raised ECP, which has also been reported without eosinophilia in chronic airflow limitation and natural colds $(10,21,22)$. A sputum neutrophilia also occurs in smokers with $(10,21)$ or without (5) chronic airflow limitation, with viral infections (22), and with exposure to endotoxin (23) or ozone (24). Neutrophilia is, therefore, quite a nonspecific response, and its cause in the present study is unclear.

An unexpected finding was elevated levels of sputum fibrinogen and albumin that we attribute to microvascular leakage. This observation is in line with bronchial biopsies of children with chronic cough showing marked increase in the percentage of area of intercellular spaces denoting airway edema (25). Increased microvascular leakage is reported in other airway conditions including viral infection (22) and smokers with chronic airflow limitation (10), conditions also associated with neutrophilia. However, in the present study, it also occurred in some subjects in the absence of abnormal sputum cell counts. IL-8 and other proinflammatory mediators, such as substance P, may be involved.

Substance $\mathrm{P}$ is a tachykinin localized in a population of nonmyelinated afferent sensory neurons in the respiratory tract. It has a variety of effects on the airways of the lungs including airway constriction in asthmatics, cough, vasodilata- tion, microvascular leakage, submucosal gland secretion and chemoattraction for eosinophils and neutrophils (26). Whereas most of the evidence of the effects of substance $P$ on leakage is derived from animal studies, the intradermal injection of substance P causes a wheal in human skin (27), indicating its capacity to cause microvascular leakage in man. In the present study, substance P levels were strongly correlated with albumin levels but not with fibrinogen. Although this association does not imply causality, it seems reasonable to speculate that substance $\mathrm{P}$ could have produced or enhanced microvascular leakage in these patients. Furthermore, our results are in keeping with a recent report by Baumgarten et al (28), who demonstrated generation of substance $P$ after a nasal challenge with bradykinin, and a strong correlation between nasal mucosa edema and hypersecretion of substance $P$.

This is the first randomized, controlled trial to examine the effects of treatment with inhaled steroid on cough discomfort as well as inflammatory indexes. Budesonide $800 \mu \mathrm{g}$ daily for two or four weeks had no effect. The results emphasize the importance of inclusion of a placebo arm to the treatment because any apparent improvements seen with budesonide were matched by placebo. The lack of beneficial effect of budesonide on cough scores or sputum inflammatory indexes is probably because the cause of the cough was not associated with sputum eosinophilia. Sputum eosinophilia seems to predict benefit from steroid treatment in chronic cough without asthma (17), in asthma (8) and in smokers with chronic airflow limitation $(9,10)$. Our results are confirmed by Gibson et al (17), who also reported that patients with nonasthmatic chronic cough who did not respond to treatment with inhaled steroid were those without eosinophilia in bronchoalveolar lavage.

The lack of an effect of budesonide on airway inflammation may be considered to be due to the small number of patients who had successful sputum inductions at each visit. However, this does not seem likely for two reasons. First, we have shown in previous studies significant effects of corti- 
costeroid treatment on sputum indexes within (8) and between small groups of subjects (29), which were paralleled by improvement in clinical parameters. Second, this lack of an effect of budesonide in this study was accompanied by an absence of any clinically important effect on cough discomfort, irrespective of whether the analysis was on the entire sample or the subgroup of patients with successful sputum production. We also considered whether the lack of effect of budesonide was due to the inclusion of patients with a longstanding cough or to the short duration of budesonide treatment. These seems unlikely because prolonged cough, after only one week of treatment with an inhaled steroid, has been highly responsive to treatment in subjects with a nonasthmatic cough associated with sputum eosinophilia (7).

\section{REFERENCES}

1. Irvin RS, Curley FJ, French CL. Chronic cough. The spectrum and frequency of causes, key components of the diagnostic evaluation, and outcome of specific therapeutic. Am Rev Respir Dis 1990;141:640-7.

2. Carney IK, Gibson PG, Murree-Allen K, Saltos N, Olson LG, Hensley MJ. A systematic evaluation of mechanisms of chronic cough. Am J Respir Crit Care Med 1997;156:211-6.

3. Mello JC, Irwin LS, Curley FJ. Predictive values of the character, timing, and complications of chronic cough in diagnosing its cause. Arch Intern Med 1996;156:997-1003.

4. McGarvey LPA, Heaney LG, Lawson JT, et al. Evaluation and outcome of patients with chronic non-productive cough using a comprehensive diagnostic protocol. Thorax 1998;53:738-43.

5. Pizzichini E, Pizzichini MMM, Efthimiadis A, et al. Indices of airway inflammation in induced sputum: reproducibility and validity of cell and fluid-phase measurements. Am J Respir Crit Care Med 1996; $154: 308-17$.

6. Gibson PG, Dolovich J, Denburg J, Ramsdale EH, Hargreave FE. Chronic cough: eosinophilic bronchitis without asthma. Lancet 1989;i:1346-8.

7. Gibson PG, Hargreave FE, Girgis-Gabardo A, Morris M, Denburg JA, Dolovich J. Chronic cough with eosinophilic bronchitis: examination for variable airflow obstruction and response to corticosteroid. Clin Exp Allergy 1995;25:127-32.

8. Pizzichini MMM, Pizzichini E, Clelland L, et al. Sputum in severe exacerbations of asthma: kinetics of inflammatory indices after prednisone treatment. Am J Respir Crit Care Med 1997;155:1501-8.

9. Chanez P, Vignola AM, O'Shaugnessy T, et al. Corticosteroid reversibility in COPD is related to features of asthma. Am J Respir Crit Care Med 1997;155:1529-34.

10. Pizzichini E, Pizzichini MM, Gibson P, et al. Sputum eosinophilia predicts benefit from prednisone in smokers with chronic obstructive bronchitis. Am J Respir Crit Care Med 1998;158:1511-7.

11. Jatakanon A, Lalloo UG, Chung KF, Barnes PJ. Increased neutrophils and cytokines, TNF- $\alpha$ and IL-8, in induced sputum of non-asthmatic patients with chronic dry cough. Thorax 1999;54:234-7.

12. Standardization of spirometry - 1987 update. Statement of the American Thoracic Society. Am Rev Respir Dis 1987;136:1285-98.

13. Crapo RO, Morris AH, Gardner RM. Reference spirometric values using techniques and equipment that meets ATS recommendation. Am Rev Respir Dis 1981;123:659-64.

14. Juniper EF, Cockcroft DW, Hargreave FE. Histamine and Methacholine Inhalation Tests: A Laboratory Tidal Breathing Protocol, 2nd edn. Lund: Astra Draco AB, 1994.

15. Pepys J. Skin test in diagnosis. In: Gell PGH, Coombs RRA, Lachmann PJ, eds. Clinical Aspects of Immunology, 3rd edn. Oxford: Blackwell Scientific Publications, 1975:55-80.

\section{CONCLUSIONS}

In patients with nonasthmatic chronic cough of unknown cause, the cough is associated with mild sputum neutrophilia or evidence of microvascular leakage. Cough and sputum inflammatory indices are not altered by treatment with budesonide, possibly because their cause was not associated with sputum eosinophilia.

ACKNOWLEDGEMENTS: Supported by a grant from Astra Pharma Inc. The authors thank the participants who agreed to take part in this study, Sharon Weston who helped with cell counts, Susan Evans who performed the fluid phase measurements, and Pharmacia Diagnostics AB, Uppsala, Sweden who provided the ECP kits.

16. Pin I, Gibson PG, Kolendowicz R, et al. Use of induced sputum cell counts to investigate airway inflammation in asthma. Thorax 1992;47:25-9.

17. Gibson PG, Zlatic K, Scott J, Sewell W, Woolley K, Saltos N. Chronic cough resembles asthma with IL-5 and granulocyte-macrophage colony-stimulating factor gene expression in bronchoalveolar cells. J Allergy Clin Immunol 1998;101:320-6.

18. Boulet LP, Milot J, Boutet M, St Georges F, Laviolette M. Airway inflammation in nonasthmatic subjects with chronic cough. Am J Respir Crit Care Med 1994;149:482-9.

19. McGarvey LPA, Forsythe P, Heaney LG, MacMahon J, Ennins M. Bronchoalveolar lavage findings in patients with chronic non-productive cough. Eur Respir J 1999;13:59-65.

20. Baggiolini M, Walz A, Kunkel SL. Neutrophil activating peptide-1/interleukin-8, a novel cytokine that stimulates neutrophils. J Clin Invest 1989;84:1045-9.

21. Keatings VM, Barnes PG. Granulocyte activation markers in induced sputum: comparison between chronic obstructive pulmonary disease, asthma and normal subjects. Am J Respir Crit Care Med 1997; 155:449-53.

22. Pizzichini MMM, Pizzichini E, Efthimiadis A, et al. Asthma and natural colds: inflammatory indices in induced sputum: A feasibility study. Am J Respir Crit Care Med 1998;158:1178-84.

23. Nightingale JA, Rogers DF, Hart LA, Kharitonov SA, Chung KF, Barnes PJ. Effect of inhaled endotoxin on induced sputum in normal, atopic, and atopic asthmatic subjects. Thorax 1998;53:563-71.

24. Fahy JV, Wong HH, Liu JT, Boushey HA. Analysis of induced sputum after air and ozone exposures in healthy subjects. Environ Res 1995;70:77-83.

25. Heino M, Juntunen-Backman K, Leijala M, Rapola J, Laitinen LA. Bronchial epithelial inflammation in children with chronic cough after early lower respiratory tract illness. Am Rev Respir Dis 1990;141:428-32.

26. Barnes PJ, Belvisi MG. Sensory neuropetides. In: Barnes PJ, Grunstein MM, Leff AR, Woolcock A, eds. Asthma, 1st edn. Philadelphia: Lippincott-Raven Publisher, 1997:1051-63.

27. Fuller RW, Conradson T, Dixon CMS, Crossman DC, Barnes PJ. Sensory neuropeptide effect in human skin. Br J Pharmacol 1987;92:781-8

28. Baumgarten CR, O'Connor A, Dokik D, Schultz KD, Kunkel G. Substance $\mathrm{P}$ is generated in vivo following nasal challenge of allergic individuals with bradykinin. Clin Exp Allergy 1997;27:1322-7.

29. Turner MO, Johnston PR, Pizzichini E, Pizzichini MMM, Hargreave FE. Anti-inflammatory effects of salmeterol compared with beclomethasone in mild exacerbations of asthma: a randomized, placebo controlled trial. Can Respir J 1998;5:261-8. 


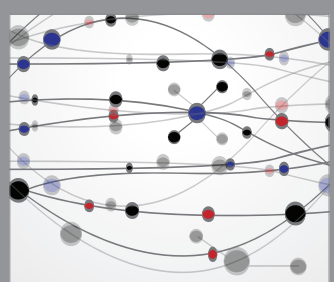

The Scientific World Journal
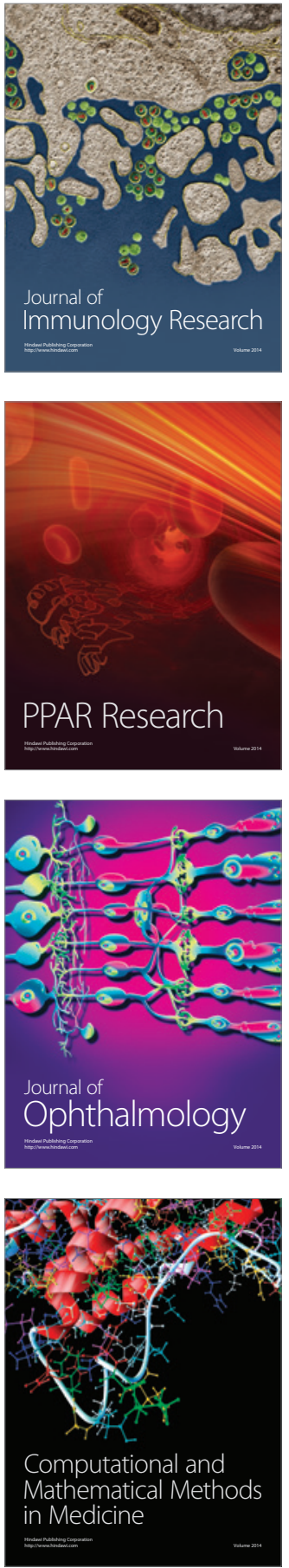

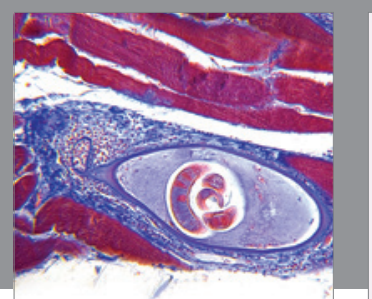

Gastroenterology Research and Practice

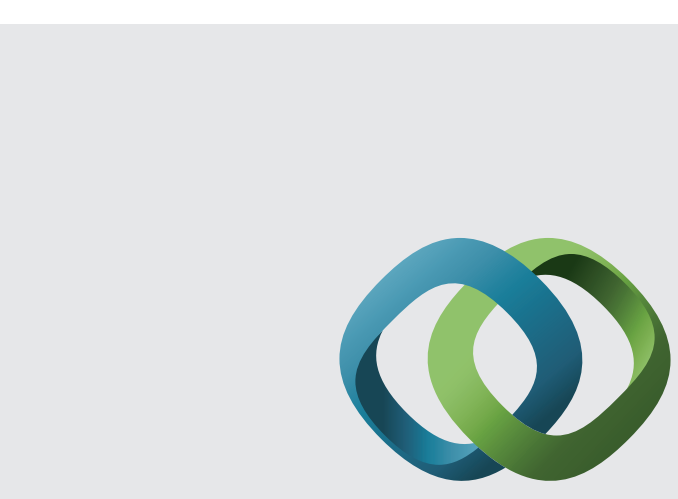

\section{Hindawi}

Submit your manuscripts at

http://www.hindawi.com
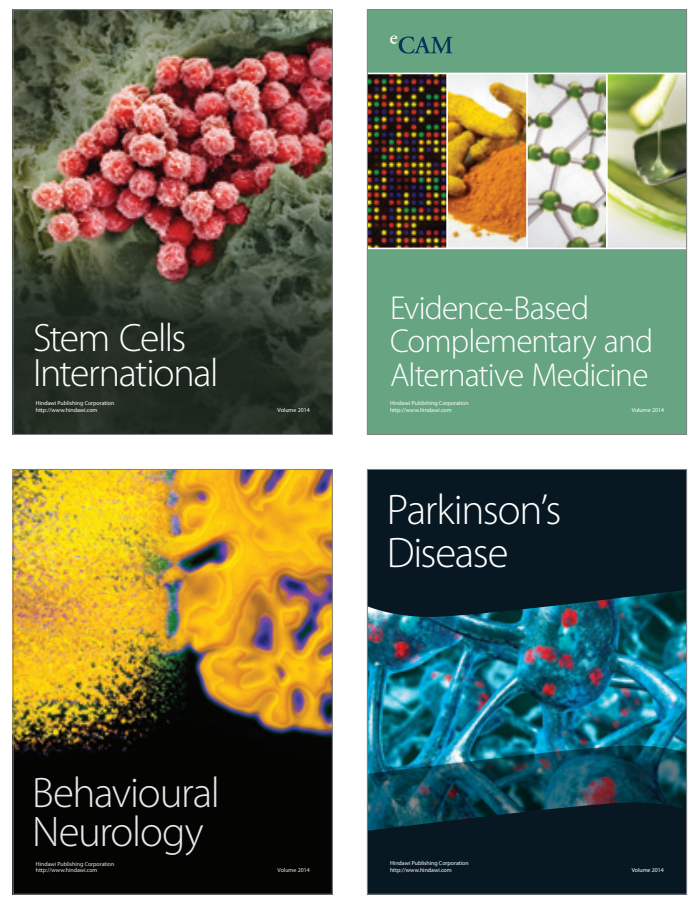
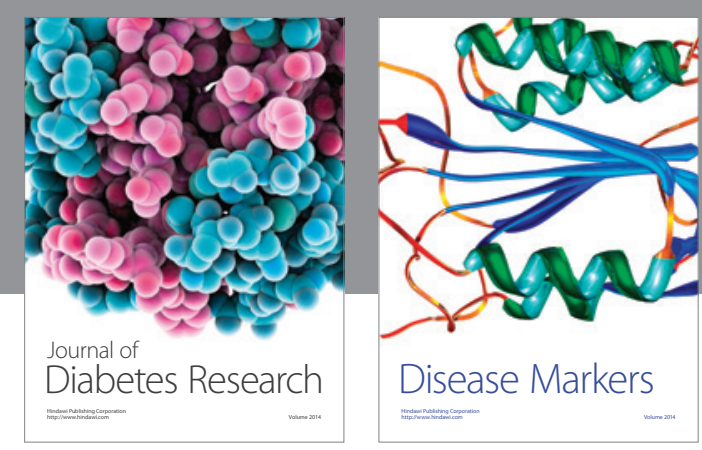

Disease Markers
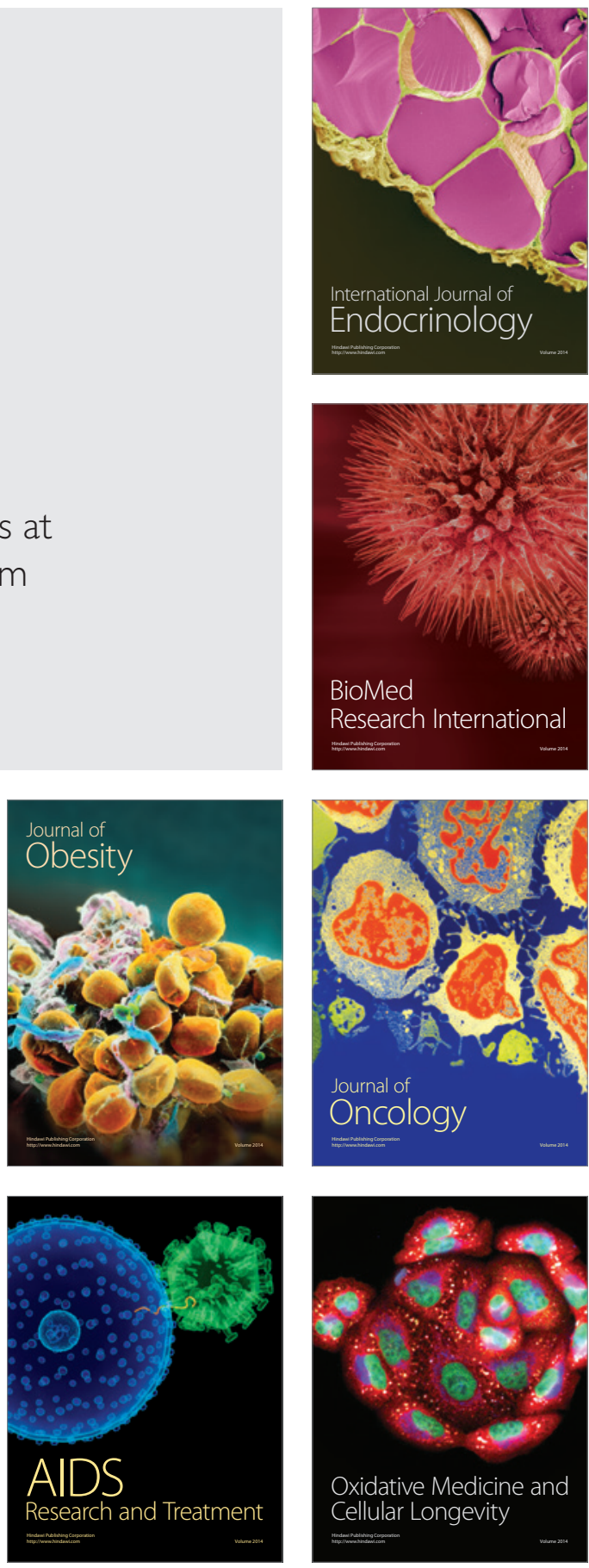